\title{
Synthesis of 9,10-Bis-ketoenaminoanthryl and 9,10-Bis- isoxazolylanthryl Linked Biscalix[4]arenes: Atropisomers and Molecular Recognitions
}

\author{
Chia-Chen Tsai, ${ }^{\dagger}$ I-Ting Ho, ${ }^{\dagger}$ Jean-Ho Chu, ${ }^{\dagger}$ Li-Ching Shen, ${ }^{\dagger}$ Shou-Ling Huang, ${ }^{\ddagger}$ \\ and Wen-Sheng Chung*, \\ ${ }^{\dagger}$ Department of Applied Chemistry, National Chiao Tung University, Hsinchu, Taiwan 30050, Republic of China \\ ${ }^{\ddagger}$ Instrumentation Center, National Taiwan University, Taipei, Taiwan 106, Republic of China
}

Supporting Information

ABSTRACT: An efficient synthetic pathway for the synthesis of biscalix[4]arenes 5-10 using 1,3-dipolar cycloaddition reactions is reported. Biscalix[4]arene $\mathbf{1 0}$ is capable of forming a complex with methyl viologen because of favorable cation $-\pi$ interactions and a proper cavity size to accommodate the guest. Moreover, biscalix[4] arenes $\mathbf{8 a}$ and $\mathbf{8 b}$ were found to be atropisomers at room temperature. These two conformers

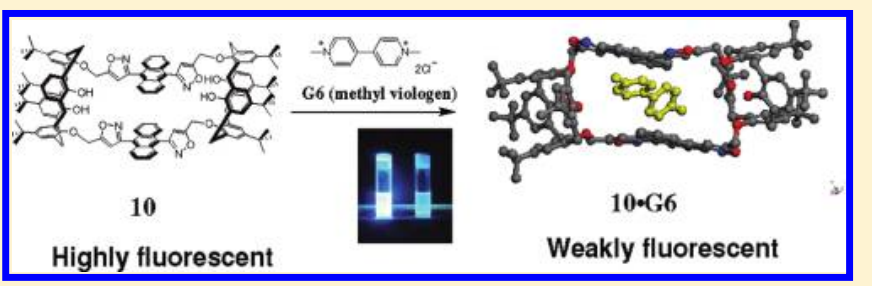
were unable to exchange at room temperature because of the restricted rotation of the $\mathrm{C}_{9}-\mathrm{C}_{11}$ or $\mathrm{C}_{10}-\mathrm{C}_{12}$ bonds of the $\beta$-amino- $\alpha, \beta$-unsaturated ketones of anthracene.

\section{INTRODUCTION}

Biscalixarenes ${ }^{1}$ have been studied extensively in recent years because the structures usually contain interesting properties including allosteric effect, ${ }^{2}$ intramolecular oscillation, ${ }^{3}$ and conformational conversion. ${ }^{4}$ An internal cavity, formed naturally through the linkage of two calixarenes, can be used as a host not only for metal ions but also for neutral molecules. For example, Gutsche and co-workers reported that 5,5'biscalix $[5]$ arene can be used to selectively recognize fullerene[70] over fullerene[60], where the biscalix[5] arene undergoes an anti to syn conformational change upon complexation with a fullerene to maximize the interaction between host and guest. ${ }^{4 a}$

Methyl viologen is one of the most widely used herbicides in the world. It is shown to be toxic to humans and animals and is linked to the development of Parkinson's disease; ${ }^{5}$ accordingly, it is highly desirable to have a selective and sensitive method in the fast screening of methyl viologen. Currently, most of the detection of methyl viologen relies on ${ }^{1} \mathrm{H}$ NMR titration experiments using various macrocycles such as calix[4]arenes, ${ }^{6}$ crown ethers, ${ }^{7}$ triptycenes, ${ }^{8}$ and pillar[5] arenes. ${ }^{9}$ There has been very few reports on the fluorescent sensing of methyl viologen. To the best of our knowledge, Wagner and Isaacs were the first to report a fluorescent sensing of methyl viologen using cucurbit[6] uril as the host. ${ }^{10}$ The design and synthesis of a highly specific fluorescent sensor for viologen is still demanding, and it would have following benefits: high sensitivity, easy to use, low cost, and low background interference.

We have been using a strategy to construct a variety of functionalized isoxazoline and isoxazole unit(s) onto the calix[4]arene skeletons through double and/or quadruple 1,3- dipolar cycloaddition reactions of alkenes/alkynes with aryl nitrile oxides. ${ }^{11,12}$ In order to further expand the diversity of biscalix[4]arenes, we also explored possible ring-opening reactions of mono- and bis-isoxazole substituted calix[4]arenes. $^{12-14}$ To our delight, $\mathrm{Mo}(\mathrm{CO})_{6}$-mediated ring-opening reactions of these isoxazole-substituted calix[4]arenes led to the formation of various enaminone $(\beta$-amino- $\alpha, \beta$-unsaturated ketone) appended calix[4]arenes efficiently. ${ }^{14}$ Using the protocol described above, we report herein the synthesis of biscalix[4] arenes 6-10, which contain an ellipsoidal cavity and/ or an anthryl group as fluorophore. The ring-opening reaction of biscalixarene 7 led to two 9,10-bis-ketoenaminoanthryl biscalix[4]arenes, $\mathbf{8 a}$ and $\mathbf{8 b}$, which showed interesting atropisomeric properties. ${ }^{15}$ The application of biscalix[4]arene 10 as a fluorescent chemosensor for methyl viologen is also studied.

\section{RESULTS AND DISCUSSION}

The synthetic pathways for biscalix[4]arenes 5, 7, and $\mathbf{1 0}$ are depicted in Scheme 1. Our synthetic strategy for linking two calix[4] arenes started with the double 1,3-dipolar cycloaddition reactions between aryl dinitrile oxides (prepared in situ from 3 and 4) and propargyl ether to yield 5 and 7 in $43 \%$ and $62 \%$ yield, respectively. In principle, the quadruple cycloaddition reactions, of two bispropargyloxycalix[4] arenes 2 with two anthracene-9,10-bis(carbonitrile oxide) 4, should lead to a doubly bridged biscalix[4] arene 10; however, when $2(5.5 \mathrm{mM})$ was refluxed with $4(5.5 \mathrm{mM})$ in THF for $24 \mathrm{~h}$, the reaction mixture became very messy and was difficult to be purified by

Received: December 7, 2011

Published: February 21, 2012 
Scheme 1. Syntheses of Biscalix[4]arenes 5, 7, and 10

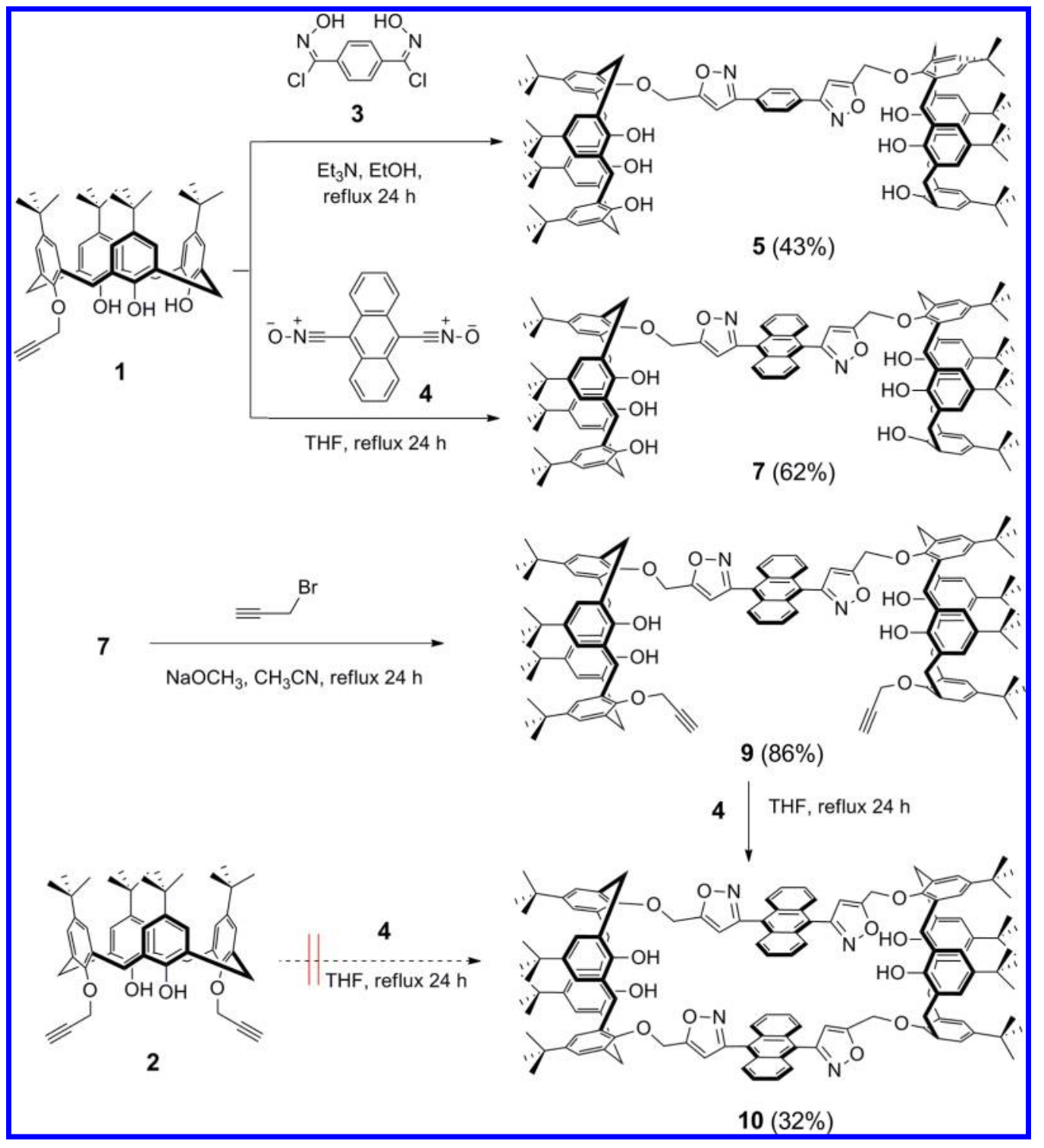

column chromatography. Alternatively, the doubly bridged biscalix[4] arene 10 could be synthesized via a two-step reaction sequence starting from 7. First, the bispropargyl ether substituted biscalix[4]arene 9 was obtained in $86 \%$ yield through $S_{N} 2$ reaction of 7 with 2 equiv of propargyl bromide under basic conditions.

Second, a double 1,3-dipolar cycloaddition of the bispropargyl ether substituted biscalix[4] arene 9 with 4 afforded the doubly bridged biscalix[4] arene 10 in $32 \%$ yield. ${ }^{1} \mathrm{H}$ NMR spectrum of the methylene bridge protons and the isoxazole protons of biscalix[4]arene $\mathbf{1 0}$ showed only two singlets implying that its structure was highly symmetrical.

The $\mathrm{N}-\mathrm{O}$ bond cleavage of the isoxazole units of biscalix[4]arenes 5 by $\mathrm{Mo}(\mathrm{CO})_{6}$-mediated ring-opening reaction led to the formation of 1,4-bisketoenaminophenyl biscalix[4]arene 6 and recovered calix[4] arene in 32 and $40 \%$ yield, respectively. Under similar reaction conditions, the ringopening reaction of 7 gave the 9,10-bisketoenaminoanthyl biscalix[4] arenes $\mathbf{8 a}$ and $\mathbf{8 b}$, as a mixture of atropisomers, in $67 \%$ yield (Scheme 2). ${ }^{1} \mathrm{H}$ NMR spectra of these compounds showed that the amino protons of the ketoenaminos appeared as two singlets: one around $\delta 10.0-10.2$ (due to H-bonding with the carbonyl groups) and the other around $\delta 5.6-5.8 \mathrm{ppm}$. The structures of all products $(\mathbf{5 - 1 0})$ were fully characterized by spectral data including ${ }^{1} \mathrm{H}$ and ${ }^{13} \mathrm{C}$ NMR (Figures S12-S27, Supporting Information), mass, and high resolution mass spectrometry (Experimental Section). Furthermore, the structure of biscalix[4]arene 10 was confirmed by a singlecrystal X-ray crystallography analysis (Figure 1). The X-ray crystal structure of $\mathbf{1 0}$ clearly shows that it contains a rectangular cone cavity. This biscalix[4] arene is a nanometersized macrocycle ( $3.0 \mathrm{~nm}$ long) with two parallel anthracene moieties, and the distance between the two anthracene planes is 4.0 A. The two anthracenes are not in juxtaposition; they are slightly staggered. The cavity of $\mathbf{1 0}$ is constructed by the walls of two parallel anthracene moieties and two tail-to-tail calix [4] arenes; therefore, it has a potential for $\pi-\pi$ interaction and recognition of dications by the two bridged calix[4]arenes. To this end, we envisaged that methyl viologen and its analogues may have the potential to be snugly fit into the rectangular cavity of biscalix[4]arene $\mathbf{1 0}$. 
Scheme 2. Syntheses of Ring-Opened Biscalix[4]arene 6 and Atopisomers $8 \mathrm{a}$ and $8 \mathrm{~b}$
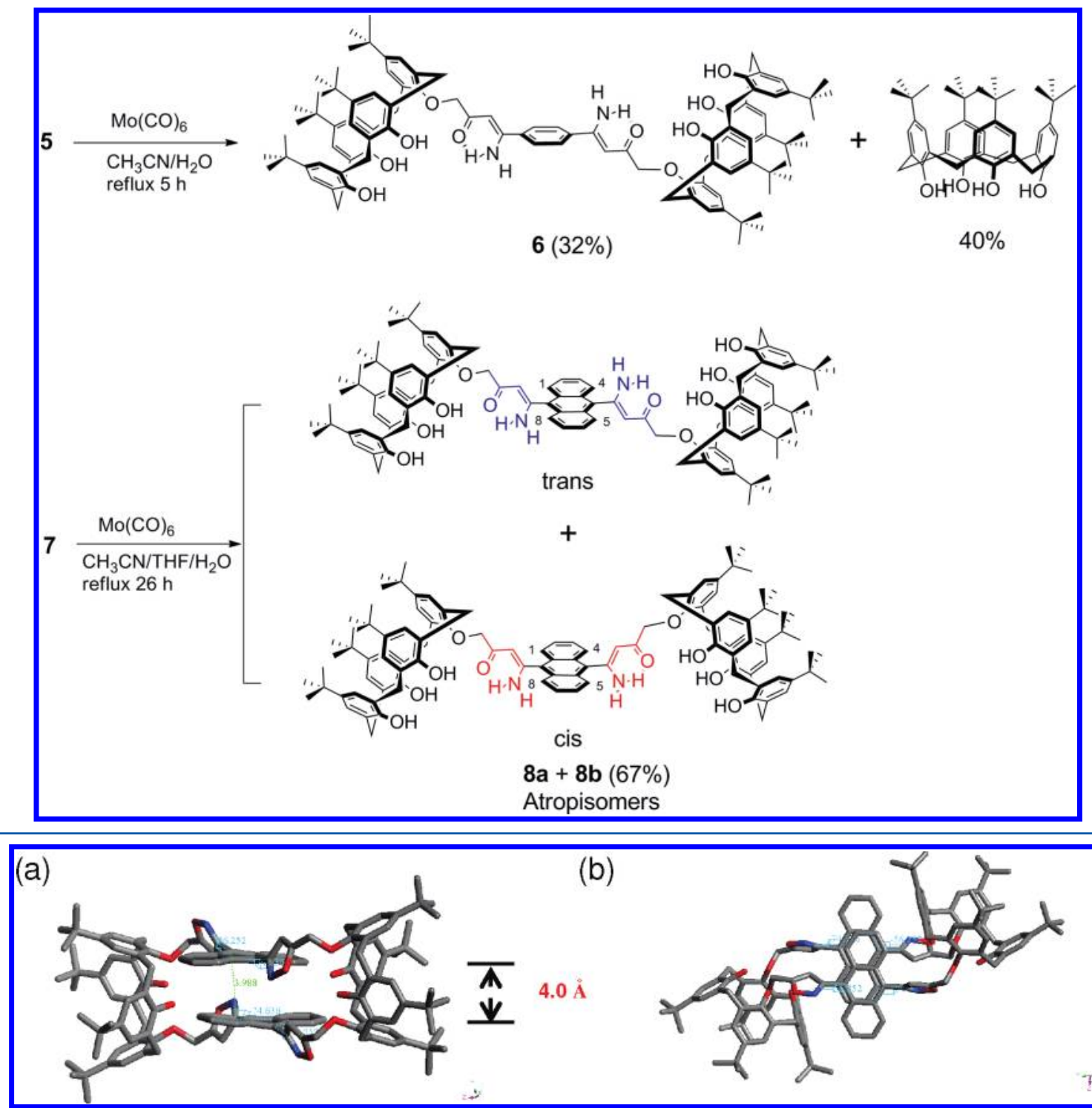

(b)

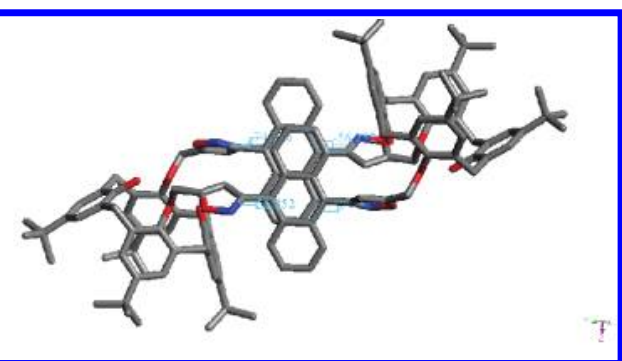

Figure 1. (a) X-ray single crystal structure of biscalix[4]arene 10 and (b) a snapshot of the structure in (a) by $90^{\circ}$ rotation in its horizontal-axis.

Unexpectedly, the ${ }^{1} \mathrm{H}$ NMR spectra of the ring-opened products 8 clearly showed two sets of signals (Figure $2 \mathrm{~b}$ ), indicating the existence of two conformational isomers or socalled atropisomers. ${ }^{15}$ In contrast, the ring-opened product 6 , from the reaction of 1,4-bisisoxazolylphenyl substituted biscalix[4]arene 5, showed only one set of proton signals (Figures 2a, S1, and S2, Supporting Information).

To determine whether steric hindrance between the anthryl and the ketoenamino groups or steric bulkiness of the calix[4]arene plays the crucial role in making compounds 8 atropisomers, we synthesized a control compound $\mathbf{1 2}$, in which the two calix[4]arenes were replaced by two para-t-butylphenyl ether groups (Scheme 3). The ${ }^{1} \mathrm{H}$ NMR spectrum of 12 at room temperature gives rise to two well-resolved sets of signals (Figure S26, Supporting Information). The results imply that adding a bulky substituent or not at a remote position from the 9,10-bisketoenamino substituted anthracene did not affect its atropisomeric properties. There is no need to replace $t$-butyloxy group with a bulkier substituent, such as calix[4]arene, to achieve atropisomeric properties in the 9,10-bisketoenamino substituted anthracene. Note that no atropisomeric properties were found for the phenyl bridged 1,4-biscalix[4]arene 6 (Figure 2a); thus, the hindered rotation in the 9,10bisketoenamino substituted anthracene of 8 or 12 plays a key role in forming atropisomers.

${ }^{1} \mathrm{H}$ NMR spectra of the two biscalixarenes $\mathbf{8 a}$ and $\mathbf{8 b}$ show that some of their signals are separated and allowed for area integrations. At room temperature $(298 \mathrm{~K})$, the ring-opened products $\mathbf{8 a}$ and $\mathbf{8 b}$ exist as a mixture of conformers with a ratio of 46:54 in $\mathrm{CDCl}_{3}$ (Figures S2 and S3, Supporting Information). However, the assignment of the cis- or transatropisomers cannot be unambiguously determined yet. We tried to separate the atropisomers $\mathbf{8} \mathbf{a}$ and $\mathbf{8 b}$ by HPLC using various columns; ${ }^{16}$ however, it was unsuccessful. Variabletemperature NMR studies at temperatures as high as $393 \mathrm{~K}$ (sample started to decompose) showed that the two sets of proton signals of $\mathbf{8 a}$ and $\mathbf{8 b}$ did not have any symptoms of merging (Figures S4 and S5, Supporting Information), implying a very high energy barrier for the rotations of $\mathrm{C}_{9}-\mathrm{C}_{11}$ and $\mathrm{C}_{10}-$ $\mathrm{C}_{12}$ bonds. ${ }^{15 \mathrm{e}, \mathrm{f}}$ The energy barriers for the restricted rotation in 


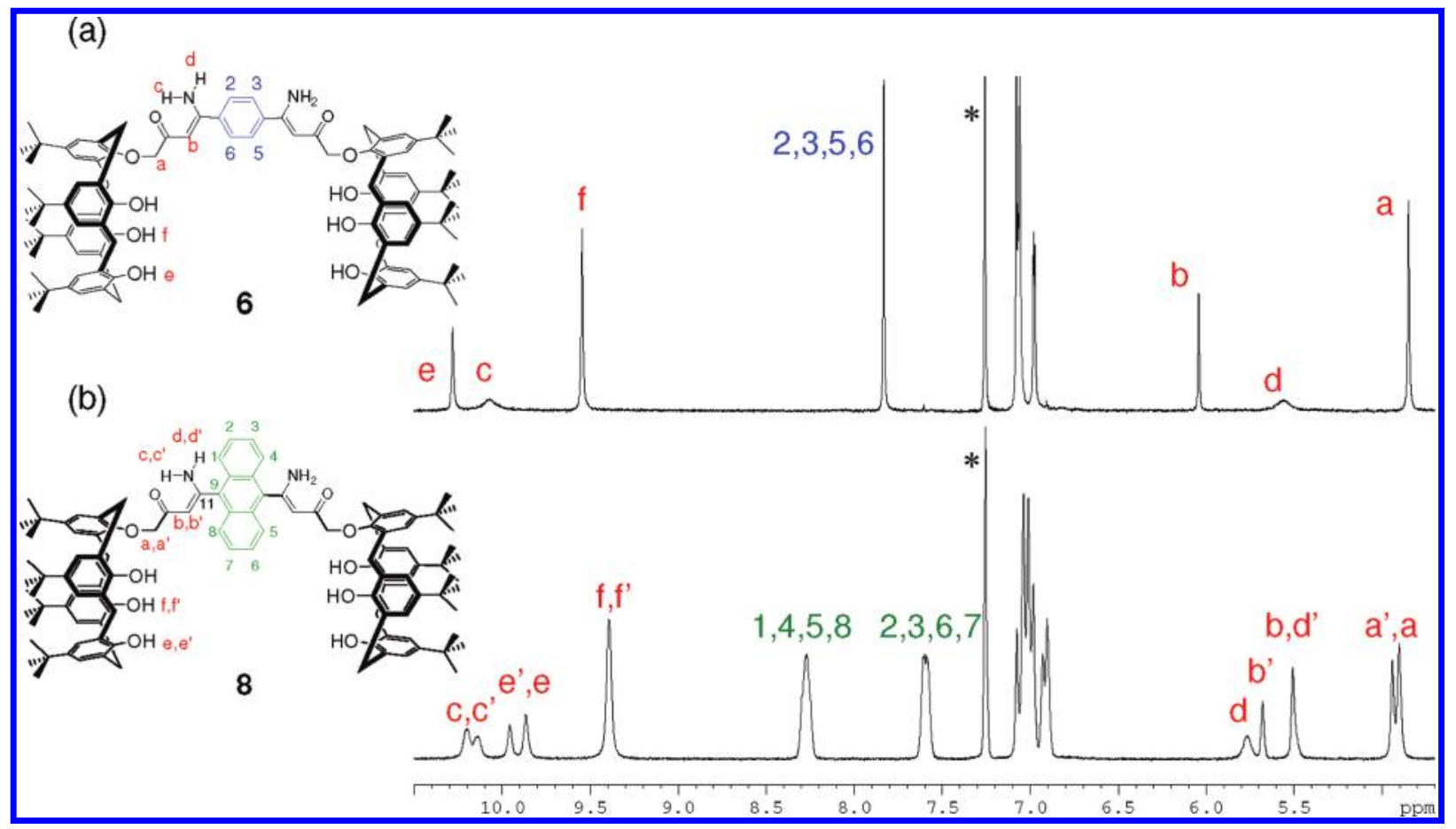

Figure 2. ${ }^{1} \mathrm{H}$ NMR spectra of the ring-opened products (a) 6 and (b) 8, where * denotes signals from the residual of chloroform- $d$. In spectrum (b), the signals labeled with a prime come from atropisomers.

Scheme 3. Synthesis of Atropisomers 12a and 12b

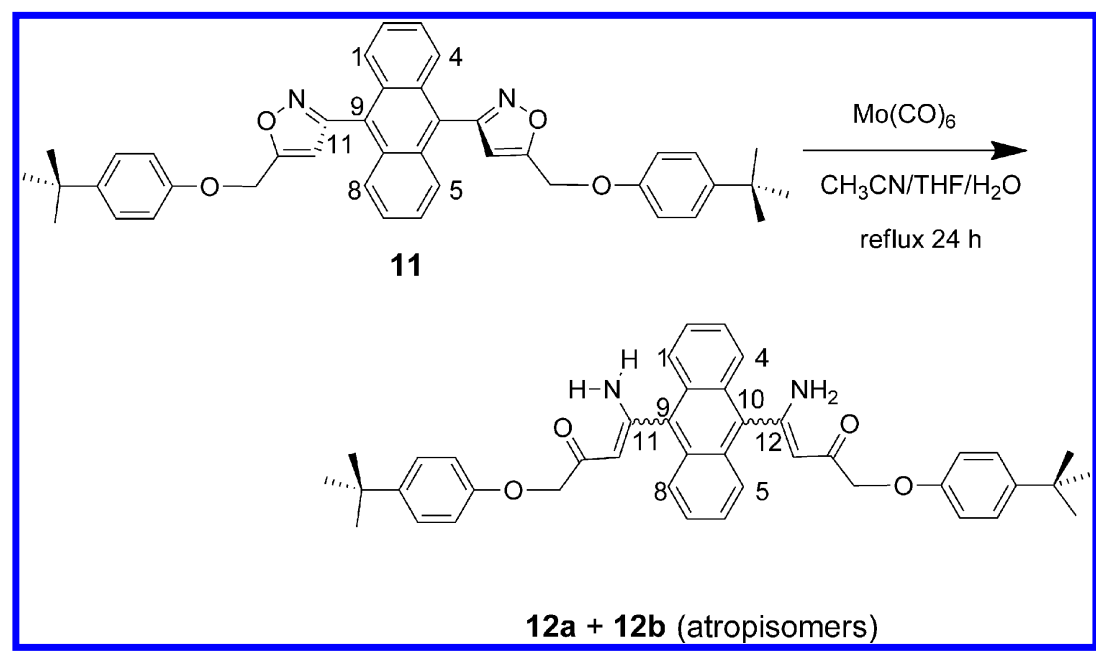

9-phenylanthracenes have been predicted by DFT calculations ${ }^{15}$ and confirmed experimentally by VT $\mathrm{NMR}^{15 e, 17}$ to be $\sim 21 \mathrm{kcal} \mathrm{mol}^{-1}$. On the other hand, the simplicity of the NMR spectra of 7 even at $-50{ }^{\circ} \mathrm{C}$ (Figures S6, Supporting Information) implies that rapid rotation occurs at this temperature and that there is a very low energy barrier of the rotations of $C_{9}-C_{11}$ and $C_{10}-C_{12}$ in 7 . The rotational energy barrier of the bis-isoxazole substituted anthracene 7 is estimated to be smaller than $10 \mathrm{kcal} \mathrm{mol}^{-1}$. $^{18}$

The normalized fluorescence spectra of biscalix[4]arenes 7, $\mathbf{1 0}$ and control compound $\mathbf{1 1}$ are shown in Figure 3. Biscalix[4] arene 10 displayed a broader emission band $\left(\lambda_{\max }\right.$ at $443 \mathrm{~nm}$ ) compared to those of biscalix [4] arene 7 and control compound 11 (both showed a $\lambda_{\max }$ at $432 \mathrm{~nm}$ ). The results implied that an intramolecular $\pi-\pi$ interaction of the two parallel anthracenes of biscalix[4]arene $\mathbf{1 0}$ should have occurred in cosolvent $\mathrm{MeOH} / \mathrm{CHCl}_{3}$ (v/v, 1:2), which led to a longer emission wavelength.

Since biscalix[4]arene 10 contains anthracenes as fluorophores, we then used it in fast screening on a series of aromatic guests, alkyldiamines, and methyl viologen (G1-G13, Chart 1) using fluorescence spectroscopy. The binding properties of $\mathbf{1 0}$ in cosolvent $\mathrm{MeOH} / \mathrm{CHCl}_{3}(\mathrm{v} / \mathrm{v}, 1: 2)$ were assessed by adding 200 equiv of various guests, and their relative fluorescence intensity changes are shown in Figure 4. There was basically no (or very small) change in the fluorescence spectra of biscalix[4] arene 10 when it was mixed with excess aromatic guests (G1-G5) and alkyldiamines (G7-G13). To our delight, only methyl viologen (G6) caused a significant quenching on the fluorescence of biscalix[4]arene 10 (Figures 4 and 5). The fluorescence quantum yield of 10 was determined to be $0.80 \pm 0.02$ using 9,10-diphenylanthracene 


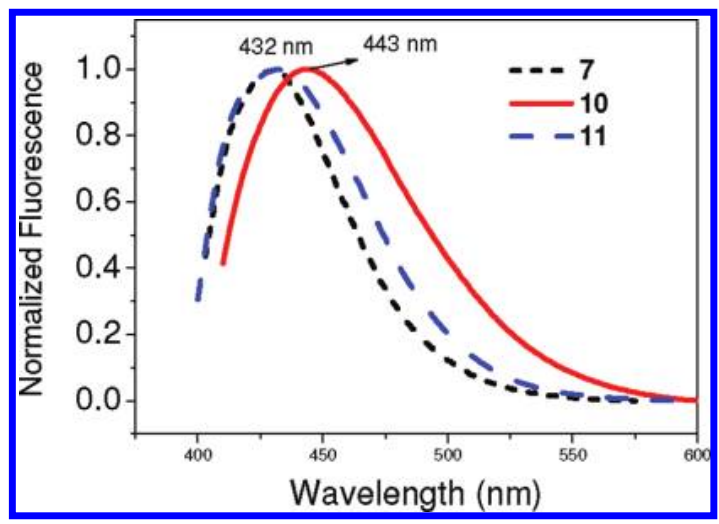

Figure 3. Normalized fluorescence spectra of biscalixarenes 7, 10 and control compound $11\left(10 \mu \mathrm{M}, \mathrm{MeOH} / \mathrm{CHCl}_{3}(\mathrm{v} / \mathrm{v}, 1: 2)\right)$. Excitation wavelength was at $393 \mathrm{~nm}$ for $7,395 \mathrm{~nm}$ for $\mathbf{1 0}$, and $392 \mathrm{~nm}$ for $\mathbf{1 1}$.

as a standard. ${ }^{19}$ Upon titration with G6, the fluorescence intensity of $\mathbf{1 0}$ gradually decreased, which gave a fluorescence quantum yield of $0.57 \pm 0.01$ (30\% decrease) at 200 equiv of G6. The association constant of complex $10 \cdot \mathrm{G} 6$ was determined to be $137.4 \pm 7.6 \mathrm{M}^{-1}$ by a Stern-Volmer plot ${ }^{20}$ (Figure $5 b$ ). Furthermore, the excimer emission of $\mathbf{1 0}$ was slightly blue-shifted at high equivalents of G6, indicating that the $\pi-\pi$ interaction of the two parallel anthracenes of biscalix[4]arene $\mathbf{1 0}$ was reduced. The results imply that G6 might have been embedded into the cavity of biscalix[4]arene 10, hence favoring the monomer emission compared to that of the excimer.

${ }^{1} \mathrm{H}$ NMR titration experiments of biscalix[4] arene 10 with methyl viologen (G6) were also carried out to shed light on its binding mode (see Figures S7 and S8, Supporting Information). The proton signals of the anthracene of the host $\mathbf{1 0}$ were slightly upfield shifted by the addition of G6, which is consistent with the inclusion of G6 in the cavity of $\mathbf{1 0}$. Moreover, we also found that the proton signals of G6 were broadened and high field shifted in the presence of 10 equiv of 10 (Figure S8, Supporting Information). Diffusion-ordered NMR spectroscopy (DOSY) has been particularly useful in the characterization of complex host-guest systems in solution. ${ }^{21}$ Thus, 2D DOSY experiments were used to investigate the complex between biscalixarene $\mathbf{1 0}$ and G6. When a 1:1 mixture of 10 and $\mathbf{G 6}$ was measured in $\mathrm{CD}_{3} \mathrm{OD} / \mathrm{CDCl}_{3}$ (v/v, 1/2) at $295 \mathrm{~K}$, the diffusion coefficients for host 10 and guest G6 were determined to be $3.16 \times 10^{-10}$ and $6.03 \times 10^{-10} \mathrm{~m}^{2} / \mathrm{s}$, respectively. However, when 100 equiv of G6 with 1 equiv of 10 were measured by 2D DOSY, a new species with a different diffusion coefficient $\left(4.17 \times 10^{-10} \mathrm{~m}^{2} / \mathrm{s}\right)$ appeared. This indicates that biscalixarene 10 and methyl viologen G6 form a complex. (Figure S9, Supporting Information)

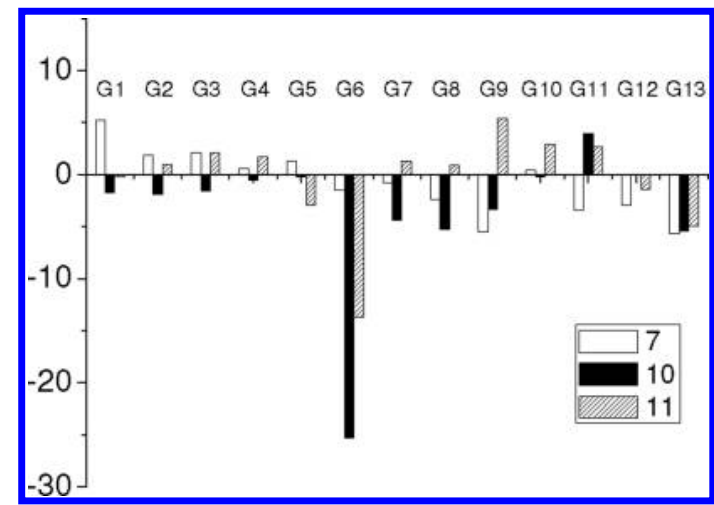

Figure 4. Relative fluorescence intensity changes $\left(\left(I-I_{0}\right) / I_{0} \times 100 \%\right)$ of biscalixarenes 7, 10 and the control compound 11 (each of $10 \mu \mathrm{M}$ ) in $\mathrm{MeOH} / \mathrm{CHCl}_{3}(\mathrm{v} / \mathrm{v}, 1: 2)$ at $298 \mathrm{~K}$ upon addition of various guests (200 equiv). Excitation wavelength was at $393 \mathrm{~nm}$ for 7, $395 \mathrm{~nm}$ for 10, and $392 \mathrm{~nm}$ for 11.

In order to know whether the rectangular cavity of biscalix[4]arene $\mathbf{1 0}$ is necessary for the recognition of methyl viologen, we synthesized a control compound 11, in which the two calix[4]arene units are replaced by two para-t-butylphenyl groups. Furthermore, the fluorescence study of the openchained biscalix[4] arene 7 toward methyl viologen G6 was also used for comparison (Figure 4). The fluorescence of the openchained biscalix[4] arene 7 showed very little change at 200 equiv of G6; ${ }^{19}$ however, the fluorescence quantum yield of the other control compound $\mathbf{1 1}$ did show some quenching by G6. The quenching effect of methyl viologen G6 on the open-chain bis-para-t-butylphenyl 11 was smaller $\left(\Phi_{\mathrm{F}}\right.$ decreased by $20 \%$ ) compared to that on the biscalix $[4]$ arene $10\left(\Phi_{\mathrm{F}}\right.$ decreased by $30 \%)$. The association constant of complex $11 \cdot \mathrm{G} 6$ was determined to be $77.6 \pm 0.6 \mathrm{M}^{-1}$ by a Stern-Volmer plot. $^{20}$ (Figure S10, Supporting Information). The ${ }^{1} \mathrm{H}$ NMR titration spectra of control compound 11 with G6 showed no change even with 10 equiv of G6 (Figure S11, Supporting Information). On the basis of these observations, we conclude that not only the cation $-\pi$ interaction but also a proper cavity size must have played important roles in the binding of methyl viologen (G6) by biscalix[4] arene 10.

Finally, an optimized geometry of 10 with $\mathbf{G 6}$ was calculated by the molecular modeling $\mathrm{DMol}^{3}$ and simulated in $\mathrm{CHCl}_{3}$ environment (Figure 6 and Tables S4-S5, Supporting Information). ${ }^{22,23}$ The $\mathrm{DMol}^{3}$ method from Material Studio 5.0 is developed by Accelrys Inc., in which the wave functions are expanded in terms of an accurate numerical basis set. We used a double-numeric quality basis set with polarization functions (DNP). The size of the DNP basis set is comparable to Gaussian $6-31 \mathrm{G}^{* *}$, but $\mathrm{DNP}$ is more accurate than a

\section{Chart 1}

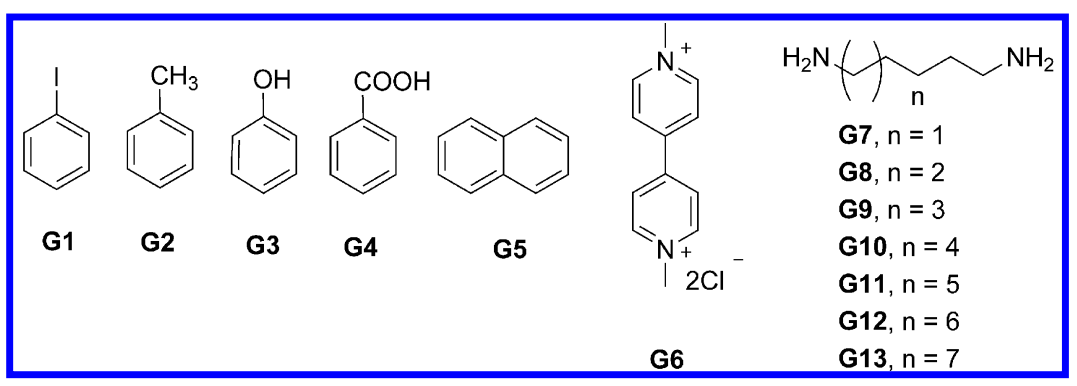



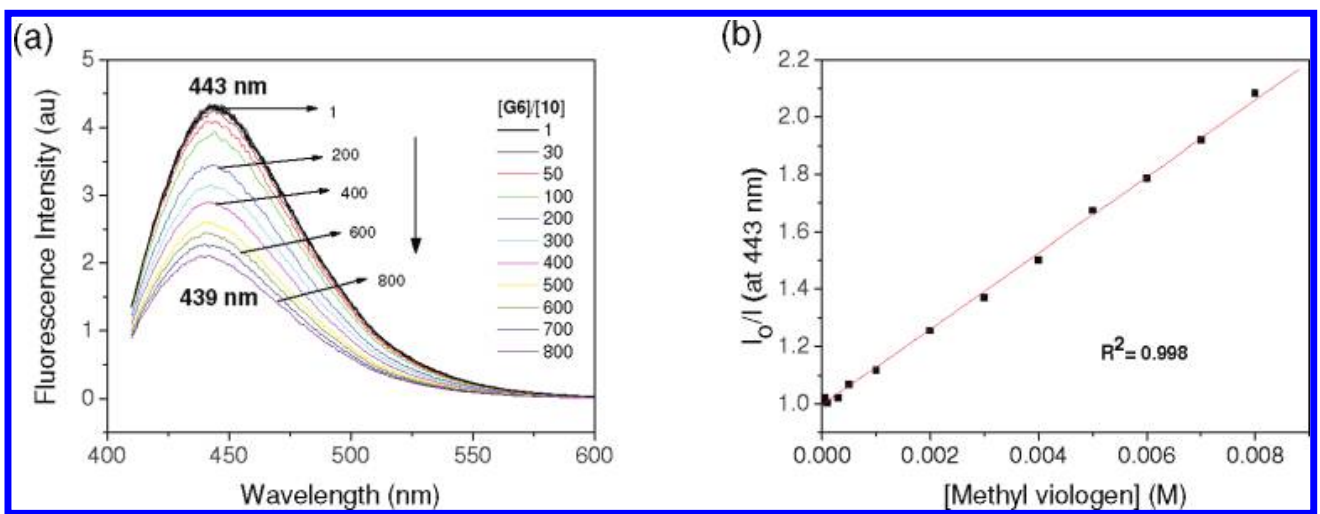

Figure 5. (a) Fluorescence emission spectra of biscalix[4]arene $10(10 \mu \mathrm{M})$ in the presence of various equivalents of methyl viologen (G6) and (b) its corresponding Stern-Volmer plot using the intensity at $443 \mathrm{~nm}$ as a parameter $\left(K_{\mathrm{a}}=137.4 \pm 7.6 \mathrm{M}^{-1}\right)$. All measurements were in a cosolvent of $\mathrm{MeOH} / \mathrm{CHCl}_{3}$ (v/v, 1:2), and the excitation wavelength was $395 \mathrm{~nm}$.

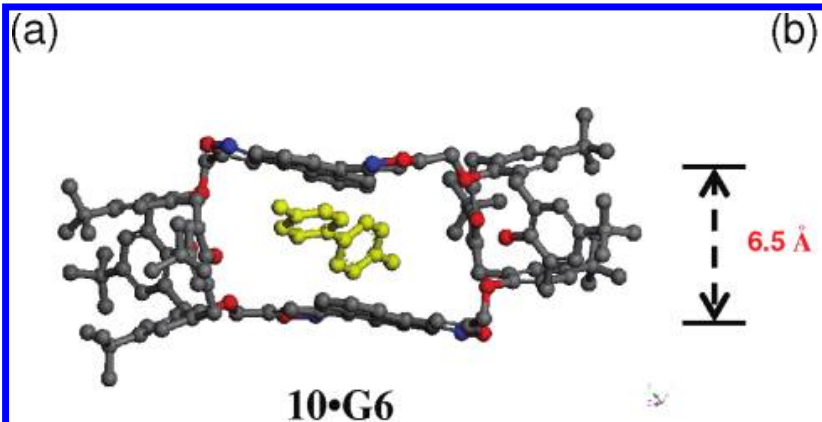

b)

$10 \cdot G 6$

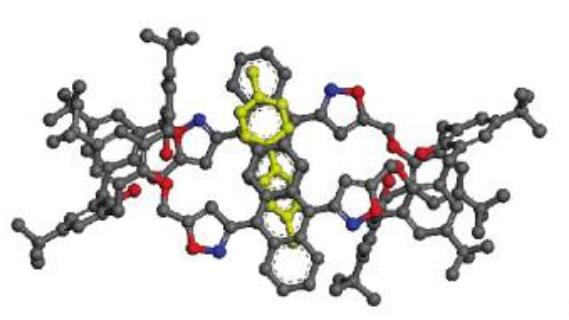

10•G6

Figure 6. A possible binding mode of the complexation of biscalix[4] arene $\mathbf{1 0}$ with G6 (a) side view and (b) top view.

Gaussian basis set of the same size. ${ }^{23}$ The tolerances of the energy, gradient, and displacement convergences were $2 \times 10^{-5}$ $\mathrm{Ha}, 4 \times 10^{-3} \mathrm{Ha} \AA^{-1}$, and $5 \times 10^{-3} \AA$, respectively. ${ }^{23 \mathrm{~b}}$ The optimized geometries of 10 with $\mathbf{G 6}$ by calculation showed a sandwich-like structure. The distance between two anthracenes of 10 increased from $4.0 \AA$ (crystal) to ca. $6.5 \AA$ when the G6 was embedded into the cavity of biscalix[4]arene 10. The results explain why the excimer emission of 10 was slightly blue-shifted.

\section{CONCLUSION}

Using a two-step reaction sequence, we have successfully synthesized a novel fluorescent biscalix[4] arene 10 with rectangular cavity. The biscalix[4]arene 10, with two parallel anthracene units, was found to show some affinity to dication molecules such as methyl viologen (G6). Although the binding constant of biscalix[4] arene $\mathbf{1 0}$ with G6 is small (137.4 \pm 7.6 $\mathrm{M}^{-1}$ ), it has the advantages of fast and easy screening by fluorescence spectroscopy. From a comparison of the results with two other control compounds ( 7 and 11), we believe that the cation $-\pi$ interaction as well as a proper cavity size play key roles in the complexation of biscalix[4]arene $\mathbf{1 0}$ with G6. Moreover, 2D DOSY experiments provided strong evidence to support the complex formation between $\mathbf{1 0}$ and G6.

We also found that not only 9,10-bisketoenaminoanthryl biscalix[4]arenes (8a and $\mathbf{8 b}$ ) but also 9,10-bisketoenaminoanthryl bis-t-butyl-phenol ethers (12a and $12 b)$ are atropisomers, where hindered rotation between the ketoenamino group and the nearby $\mathrm{C}-\mathrm{H}$ hydrogens of the anthracene were the key features. The estimated energy barriers for the restricted rotation of in the 9,10-bisketoenaminoanthryl derivatives $8 \mathbf{a}, \mathbf{b}$ are $>23 \mathrm{kcal} \mathrm{mol}^{-1}$ from VT NMR. In sharp contrast, the isoxazole substituted 9,10-bisisoxazolylanthryl biscalix [4]arene 7 has a much lower energy barrier on the rotation of $\mathrm{C}_{9}-\mathrm{C}_{11}$; therefore, even at temperatures as low as $-50{ }^{\circ} \mathrm{C}$, it did not show any symptom of proton NMR signal splitting between its atropisomers.

\section{EXPERIMENTAL SECTION}

General Methods. ${ }^{1} \mathrm{H}$ NMR spectra were measured with either a 300 or $500 \mathrm{MHz}$ spectrometer. Natural abundance ${ }^{13} \mathrm{C}$ NMR spectra were measured using pulse Fourier transform techniques, with a 300 or $500 \mathrm{MHz}$ NMR spectrometer operating at 75.4 and $125.7 \mathrm{MHz}$, respectively. Mass spectra were recorded in the FAB mode with $m$ nitrobenzyl alcohol (NBA) as the matrix. UV-vis and fluorescence spectra were measured with spectrometer and spectrofluorimeter using HPLC-grade solvents.

1,4-Bis-isoxazolyl-phenylmethyl Linked Biscalix[4]arene, 5. Triethylamine $(0.35 \mathrm{mmol})$ in ethanol $(1.9 \mathrm{~mL})$ was slowly added to a well-stirred solution of $1(0.40 \mathrm{~g}, 0.69 \mathrm{mmol})$ and hydroximoyl chloride $3(0.07 \mathrm{~g}, 0.31 \mathrm{mmol})$ in ethanol $(30 \mathrm{~mL})$. The reaction mixture was stirred at reflux for $24 \mathrm{~h}$ under $\mathrm{N}_{2}(\mathrm{~g})$. After evaporation of the solvent, the mixture was washed with water and extracted with dichloromethane. The organic phase was dried over $\mathrm{MgSO}_{4}$, and the solvent was removed under reduced pressure. The residue was purified by silica gel column chromatography using ethyl acetate $/ n$-hexane as eluent to give $0.20 \mathrm{~g}(42.7 \%)$ of 5 as a yellow solid: $\mathrm{mp} 178-180{ }^{\circ} \mathrm{C}$; $R_{f}=0.45$ (ethyl acetate $/ n$-hexane $\left.=1: 4\right) ;{ }^{1} \mathrm{H}$ NMR $\left(\mathrm{CDCl}_{3,} 300 \mathrm{MHz}\right)$ $\delta_{\mathrm{H}} 10.00(\mathrm{~s}, 2 \mathrm{H}), 9.16(\mathrm{~s}, 4 \mathrm{H}), 8.03(\mathrm{~s}, 4 \mathrm{H}), 7.12-6.99(\mathrm{~m}, 16 \mathrm{H}), 5.39$ $(\mathrm{s}, 4 \mathrm{H}), 4.33(\mathrm{~d}, 4 \mathrm{H}, J=13.2 \mathrm{~Hz}), 4.26(\mathrm{~d}, 4 \mathrm{H}, J=13.7 \mathrm{~Hz}), 3.46(\mathrm{~d}$, $4 \mathrm{H}, J=13.2 \mathrm{~Hz}), 3.44(\mathrm{~d}, 4 \mathrm{H}, J=13.7 \mathrm{~Hz}), 1.22-1.20(\mathrm{~m}, 72 \mathrm{H}) \mathrm{ppm}$; ${ }^{13} \mathrm{C}$ NMR $\left(\mathrm{CDCl}_{3}, 75.5 \mathrm{MHz}\right) \delta_{\mathrm{C}} 167.6(\mathrm{Cq}), 162.1(\mathrm{Cq}), 149.0$ (Cq), $148.9(\mathrm{Cq}), 148.3(\mathrm{Cq}), 147.5(\mathrm{Cq}), 143.7(\mathrm{Cq}), 143.2(\mathrm{Cq})$, $133.2(\mathrm{Cq}), 130.4(\mathrm{Cq}), 128.1(\mathrm{Cq}), 127.7(\mathrm{Cq}), 127.6(\mathrm{CH}), 127.4$ (Cq), $126.7(\mathrm{CH}), 125.8(\mathrm{CH}), 125.7(\mathrm{CH}), 125.6(\mathrm{CH}), 102.8$ $(\mathrm{CH}), 68.1\left(\mathrm{CH}_{2}\right), 34.3(\mathrm{Cq}), 34.0(\mathrm{Cq}), 33.9(\mathrm{Cq}), 32.9\left(\mathrm{CH}_{2}\right), 32.2$ 
$\left(\mathrm{CH}_{2}\right), 31.4\left(\mathrm{CH}_{3}\right), 31.2\left(\mathrm{CH}_{3}\right)$ ppm; FAB-MS $m / z 1534\left(\mathrm{M}+\mathrm{H}^{+}\right)$, $1533\left(\mathrm{M}^{+}\right)$; HRMS (FAB) calcd for $\mathrm{C}_{102} \mathrm{H}_{120} \mathrm{O}_{10} \mathrm{~N}_{2}$ 1532.8943, found 1532.8916.

1,4-Bis-ketoenamino-phenylmethyl Linked Biscalix[4]arene, 6. A mixture of $5(0.05 \mathrm{~g}, 0.03 \mathrm{mmol})$, $\mathrm{Mo}(\mathrm{CO})_{6}(0.02 \mathrm{~g}, 0.08 \mathrm{mmol})$, and $\mathrm{H}_{2} \mathrm{O}(0.2 \mathrm{~mL})$ in $\mathrm{CH}_{3} \mathrm{CN}(10 \mathrm{~mL})$ was stirred and heated at reflux for $5 \mathrm{~h}$. The solvent was removed under a vacuum, and the residue was dissolved in $10 \mathrm{~mL}$ of dichloromethane. Then, to the solution was added $10 \mathrm{~mL}$ of $\mathrm{NH}_{4} \mathrm{OH}$ (aq) to remove remaining molybdenum salts. After stirring for $1 \mathrm{~h}$, the organic layer was washed with water and 1 M EDTA (aq). The organic phase was dried over $\mathrm{MgSO}_{4}$, and the solvent was removed under reduced pressure. The residue was purified by neutral silica gel column chromatography with ethyl acetate $/ n$-hexane $(\mathrm{v} / \mathrm{v}, 1: 5)$ as eluent to give $0.016 \mathrm{~g}(31.9 \%)$ of yellow solid 6 with para-tert-butyl calix[4]arene $(40 \%)$ as a side product. 6: $\mathrm{mp} 182-184{ }^{\circ} \mathrm{C} ; R_{f}=0.1$ in ethyl acetate $/ n$-hexane $(\mathrm{v} / \mathrm{v}$, 1:3); ${ }^{1} \mathrm{H} \mathrm{NMR}\left(300 \mathrm{MHz}, \mathrm{CDCl}_{3}\right) \delta_{\mathrm{H}} 10.28(\mathrm{~s}, 2 \mathrm{H}), 10.07$ (bs, $\left.2 \mathrm{H}\right)$, $9.55(\mathrm{~s}, 4 \mathrm{H}), 7.83(\mathrm{~s}, 4 \mathrm{H}), 7.09-6.98(\mathrm{~m}, 16 \mathrm{H}), 6.04(\mathrm{~s}, 2 \mathrm{H}), 5.56(\mathrm{bs}$, $2 \mathrm{H}), 4.85(\mathrm{~s}, 4 \mathrm{H}), 4.53(\mathrm{~d}, 4 \mathrm{H}, J=12.9 \mathrm{~Hz}), 4.29(\mathrm{~d}, 4 \mathrm{H}, J=13.8 \mathrm{~Hz})$, $3.44(\mathrm{~d}, 4 \mathrm{H}, J=13.5 \mathrm{~Hz}), 3.41(\mathrm{~d}, 4 \mathrm{H}, J=12.9 \mathrm{~Hz}), 1.50-1.36(\mathrm{~m}$, $72 \mathrm{H}) \mathrm{ppm} ;{ }^{13} \mathrm{C} \mathrm{NMR}\left(\mathrm{CDCl}_{3}, 75.5 \mathrm{MHz}\right) \delta_{\mathrm{C}} 193.6(\mathrm{Cq}), 161.7(\mathrm{Cq})$, $150.3(\mathrm{Cq}), 148.3(\mathrm{Cq}), 148.0(\mathrm{Cq}), 143.5(\mathrm{Cq}), 143.0(\mathrm{Cq}), 139.2$ $(\mathrm{Cq}), 133.4(\mathrm{Cq}), 128.2(\mathrm{Cq}), 127.4(\mathrm{Cq}), 127.3(\mathrm{CH}), 126.5(\mathrm{CH})$, $125.8(\mathrm{CH}), 125.6(\mathrm{CH}), 91.1(\mathrm{CH}), 79.2\left(\mathrm{CH}_{2}\right), 34.2(\mathrm{Cq}), 34.0$ (Cq), $33.9(\mathrm{Cq}), 33.1\left(\mathrm{CH}_{2}\right), 32.3\left(\mathrm{CH}_{2}\right), 31.5\left(\mathrm{CH}_{3}\right), 31.2\left(\mathrm{CH}_{3}\right)$ ppm; FAB-MS $m / z 1539(\mathrm{M}+2), 1538\left(\mathrm{M}+\mathrm{H}^{+}\right)$; HRMS (FAB) calcd for $\mathrm{C}_{102} \mathrm{H}_{124} \mathrm{~N}_{2} \mathrm{O}_{10} 1536.9256$, found 1536.9266 .

9,10-Bis-isoxazolylanthryl-methyl Linked Biscalix[4]arene, 7. A mixture of $1(0.20 \mathrm{~g}, 0.30 \mathrm{mmol})$ and $4(0.04 \mathrm{~g}, 0.15 \mathrm{mmol})$ in THF $(15 \mathrm{~mL})$ was heated at reflux for $24 \mathrm{~h}$ under $\mathrm{N}_{2}(\mathrm{~g})$. After evaporation of the solvent, the mixture was washed with water and extracted with dichloromethane. The organic phase was dried over $\mathrm{MgSO}_{4}$, and the solvent was removed under reduced pressure. The residue was purified by silica gel column chromatography with ethyl acetate $/ n$-hexane as eluent to give $0.15 \mathrm{~g}(62.2 \%)$ of 7 as a yellow solid: $\mathrm{mp} 180-182{ }^{\circ} \mathrm{C}$; $R_{f}=0.35$ (ethyl acetate $/ n$-hexane $(\mathrm{v} / \mathrm{v}, 1: 5)$ ); ${ }^{1} \mathrm{H}$ NMR $(300 \mathrm{MHz}$, $\left.\mathrm{CDCl}_{3}\right) \delta_{\mathrm{H}} 10.13(\mathrm{~s}, 2 \mathrm{H}), 9.34(\mathrm{~s}, 4 \mathrm{H}), 8.11-8.08(\mathrm{~m}, 4 \mathrm{H}), 7.61-7.58$ $(\mathrm{m}, 4 \mathrm{H}), 7.28-7.07(\mathrm{~m}, 18 \mathrm{H}), 5.63(\mathrm{~s}, 4 \mathrm{H}), 4.55(\mathrm{~d}, 4 \mathrm{H}, J=13.2 \mathrm{~Hz})$, $4.33(\mathrm{~d}, 4 \mathrm{H}, J=13.8 \mathrm{~Hz}), 3.61(\mathrm{~d}, 4 \mathrm{H}, J=13.2 \mathrm{~Hz}), 3.51(\mathrm{~d}, 4 \mathrm{H}, J=$ $13.8 \mathrm{~Hz}), 1.33-1.29(\mathrm{~m}, 72 \mathrm{H}) \mathrm{ppm} ;{ }^{13} \mathrm{C} \mathrm{NMR}\left(\mathrm{CDCl}_{3}, 75.5 \mathrm{MHz}\right)$ $\delta_{\mathrm{C}} 167.2(\mathrm{Cq}), 161.4(\mathrm{Cq}), 149.1(\mathrm{Cq}), 148.8(\mathrm{Cq}), 148.3(\mathrm{Cq}), 147.7$ $(\mathrm{Cq}), 143.6(\mathrm{Cq}), 143.3(\mathrm{Cq}), 133.5(\mathrm{Cq}), 130.3(\mathrm{Cq}), 128.1(\mathrm{Cq})$, $127.7(\mathrm{Cq}), 127.7(\mathrm{Cq}), 126.8(\mathrm{CH}), 126.0(\mathrm{CH}), 125.9(\mathrm{CH}), 125.7$ $(\mathrm{CH}), 125.7(\mathrm{CH}), 125.5(\mathrm{Cq}), 108.8(\mathrm{CH}), 67.6\left(\mathrm{CH}_{2}\right), 34.3(\mathrm{Cq})$, $34.0(\mathrm{Cq}), 33.9(\mathrm{Cq}), 32.9\left(\mathrm{CH}_{2}\right), 32.4\left(\mathrm{CH}_{2}\right), 31.5\left(\mathrm{CH}_{3}\right), 31.2$ $\left(\mathrm{CH}_{3}\right)$ ppm; FAB-MS $m / z 1634\left(\mathrm{M}+\mathrm{H}^{+}\right), 1633\left(\mathrm{M}^{+}\right)$; HRMS (FAB) calcd for $\mathrm{C}_{110} \mathrm{H}_{124} \mathrm{O}_{10} \mathrm{~N}_{2}$ 1632.9256, found 1632.9275.

9,10-Bis-ketoenaminoanthryl Linked Biscalix[4]arene, 8. A mixture of $7(0.10 \mathrm{~g}, 0.06 \mathrm{mmol}), \mathrm{Mo}(\mathrm{CO})_{6}(0.07 \mathrm{~g}, 0.25 \mathrm{mmol})$, and 3 drops $\mathrm{H}_{2} \mathrm{O}$ in $\mathrm{THF} / \mathrm{CH}_{3} \mathrm{CN}(1 \mathrm{~mL} / 10 \mathrm{~mL})$ was stirred and heated at reflux for $5 \mathrm{~h}$. The solvent was removed under a vacuum, and the residue was dissolved in $10 \mathrm{~mL}$ of dichloromethane. Then, to the solution was added $10 \mathrm{~mL}$ of $\mathrm{NH}_{4} \mathrm{OH}$ (aq) to remove remaining molybdenum salts. After stirring for $1 \mathrm{~h}$, the organic layer was washed with water and 1 M EDTA (aq). The organic phase was dried over $\mathrm{MgSO}_{4}$, and the solvent was removed under reduced pressure. The residue was purified by neutral silica gel column chromatography with ethyl acetate $/ n$-hexane $(\mathrm{v} / \mathrm{v}, 1 / 5)$ as eluent to give $0.07 \mathrm{~g}(66.7 \%)$ of yellow solid 8a and $\mathbf{8 b}$ (atropisomers): $\mathrm{mp} 218-220^{\circ} \mathrm{C} ; R_{f}=0.43$ (ethyl acetate $/ n$-hexane (v/v, 1:3)); ${ }^{1} \mathrm{H}$ NMR $\left(300 \mathrm{MHz}, \mathrm{CDCl}_{3}\right.$ ) atropisomers $25{ }^{\circ} \mathrm{C}$, area ratio $=46: 54, \delta_{\mathrm{H}} 10.20(\mathrm{bs}, 1 \mathrm{H}), 10.14$ (bs, $1 \mathrm{H}), 9.96(\mathrm{~s}, 2 \mathrm{H}), 9.87(\mathrm{~s}, 2 \mathrm{H}), 9.39(\mathrm{~s}, 4 \mathrm{H}), 8.28-8.27(\mathrm{~m}, 4 \mathrm{H})$, 7.61-7.59 (m, 4H), 7.08-6.90 (m, 16H), $5.76(\mathrm{bs}, 1 \mathrm{H}), 5.68(\mathrm{~s}, 1 \mathrm{H})$, $5.51(\mathrm{~s}, 2 \mathrm{H}), 4.94(\mathrm{~s}, 2 \mathrm{H}), 4.90(\mathrm{~s}, 2 \mathrm{H}), 4.60-4.44(\mathrm{~m}, 4 \mathrm{H}), 3.99-$ $3.91(\mathrm{~m}, 4 \mathrm{H}), 3.42-3.21(\mathrm{~m}, 8 \mathrm{H}) 1.23-1.19(\mathrm{~m}, 72 \mathrm{H}) \mathrm{ppm} ;{ }^{13} \mathrm{C} \mathrm{NMR}$ $(75.5 \mathrm{MHz}) \delta_{\mathrm{C}} 207.1(\mathrm{Cq}), 193.5(\mathrm{Cq}), 193.2(\mathrm{Cq}), 161.5(\mathrm{Cq}), 161.2$ $(\mathrm{Cq}), 150.9(\mathrm{Cq}), 150.6(\mathrm{Cq}), 148.2(\mathrm{Cq}), 148.1,(\mathrm{Cq}), 148.1(\mathrm{Cq})$, $147.9(\mathrm{Cq}), 147.7(\mathrm{Cq}), 143.3(\mathrm{Cq}), 143.2(\mathrm{Cq}), 142.9(\mathrm{Cq}), 133.6$ $(\mathrm{Cq}), 133.5(\mathrm{Cq}), 132.8(\mathrm{Cq}), 132.7(\mathrm{Cq}), 128.2(\mathrm{Cq}), 128.1(\mathrm{Cq})$, $127.9(\mathrm{Cq}), 127.8(\mathrm{Cq}), 127.5(\mathrm{Cq}), 127.5(\mathrm{Cq}), 127.0(\mathrm{CH}), 126.9$
(CH), $126.4(\mathrm{CH}), 126.3(\mathrm{CH}), 125.9(\mathrm{CH}), 125.8(\mathrm{CH}), 125.5$ $(\mathrm{CH}), 95.3(\mathrm{CH}), 94.7(\mathrm{CH}), 78.9\left(\mathrm{CH}_{2}\right), 78.7\left(\mathrm{CH}_{2}\right), 78.2\left(\mathrm{CH}_{2}\right)$, $34.1(\mathrm{Cq}), 33.9(\mathrm{Cq}), 33.9(\mathrm{Cq}), 33.9(\mathrm{Cq}), 33.0(\mathrm{Cq}), 32.7\left(\mathrm{CH}_{2}\right)$, $32.6\left(\mathrm{CH}_{2}\right), 32.4\left(\mathrm{CH}_{2}\right), 31.5\left(\mathrm{CH}_{3}\right), 31.4\left(\mathrm{CH}_{3}\right), 31.2\left(\mathrm{CH}_{3}\right), 30.9$ $\left(\mathrm{CH}_{3}\right), 29.7\left(\mathrm{CH}_{2}\right)$ ppm; FAB-MS $m / z 1638\left(\mathrm{M}+\mathrm{H}^{+}\right), 1637\left(\mathrm{M}^{+}\right)$; HRMS (FAB) calcd for $\mathrm{C}_{110} \mathrm{H}_{128} \mathrm{~N}_{2} \mathrm{O}_{10} 1636.9569$, found 1636.9586 .

Bispropargyl Ether Substituted 9,10-Bis-isoxazolylanthrylmethyl Linked Biscalix[4]arene, 9. A mixture of 7 (0.11 g, 0.07 $\mathrm{mmol})$, sodium methoxide $(0.01 \mathrm{~g}, 0.18 \mathrm{mmol})$, and propargyl bromide $(0.04 \mathrm{~mL}, 0.34 \mathrm{mmol})$ in $\mathrm{CHCl} / \mathrm{CH}_{3} \mathrm{CN}(3 \mathrm{~mL} / 30 \mathrm{~mL})$ was stirred and heated at reflux for $24 \mathrm{~h}$. The solvent was removed under a vacuum, and the residue was purified by silica gel column chromatography with ethyl acetate $/ n$-hexane as eluent to give $0.10 \mathrm{~g}$ $(85.8 \%)$ of 9: $\mathrm{mp} 239-241{ }^{\circ} \mathrm{C} ; R_{f}=0.18$ (ethyl acetate $/ n$-hexane $=$ $1: 5)$; ${ }^{1} \mathrm{H}$ NMR $\left(300 \mathrm{MHz}, \mathrm{CDCl}_{3}\right) \delta_{\mathrm{H}} 8.00-7.96(\mathrm{~m}, 4 \mathrm{H}), 7.51-7.48$ $(\mathrm{m}, 4 \mathrm{H}), 7.25-6.74(\mathrm{~m}, 22 \mathrm{H}), 5.40(\mathrm{~s}, 4 \mathrm{H}), 4.54(\mathrm{~d}, 4 \mathrm{H}, J=2.3 \mathrm{~Hz})$, $4.36(\mathrm{~d}, 4 \mathrm{H}, J=13.2 \mathrm{~Hz}), 4.31(\mathrm{~d}, 4 \mathrm{H}, J=13.4 \mathrm{~Hz}), 3.39(\mathrm{~d}, 4 \mathrm{H}, J=$ $13.2 \mathrm{~Hz}), 3.32(\mathrm{~d}, 4 \mathrm{H}, J=13.4 \mathrm{~Hz}), 2.13(\mathrm{t}, 2 \mathrm{H}, J=2.3 \mathrm{~Hz}), 1.30-$ $1.15(\mathrm{~m}, 72 \mathrm{H}) \mathrm{ppm} ;{ }^{13} \mathrm{C}$ NMR $(75.5 \mathrm{MHz}) \delta_{\mathrm{C}} 168.5(\mathrm{Cq}), 161.0$ (Cq), $150.4(\mathrm{Cq}), 149.5(\mathrm{Cq}), 149.3(\mathrm{Cq}), 147.6(\mathrm{Cq}), 147.5(\mathrm{Cq})$, $141.7(\mathrm{Cq}), 132.6(\mathrm{Cq}), 132.4(\mathrm{Cq}), 130.2(\mathrm{Cq}), 127.8(\mathrm{Cq}), 127.8$ $(\mathrm{Cq}), 126.6(\mathrm{CH}), 126.1(\mathrm{CH}), 125.8(\mathrm{CH}), 125.7(\mathrm{Cq}), 125.6(\mathrm{CH})$, 125.1 $(\mathrm{CH}), 107.9(\mathrm{CH}), 78.2(\mathrm{Cq}), 76.2(\mathrm{Cq}), 68.2\left(\mathrm{CH}_{2}\right), 63.3$ $\left(\mathrm{CH}_{2}\right), 37.1(\mathrm{Cq}), 33.9(\mathrm{Cq}), 33.8(\mathrm{Cq}), 32.1\left(\mathrm{CH}_{2}\right), 31.9\left(\mathrm{CH}_{2}\right)$, $31.7\left(\mathrm{CH}_{3}\right), 30.9\left(\mathrm{CH}_{3}\right)$ ppm; FABMS $m / z 1709(\mathrm{M}+2), 1708(\mathrm{M}+$ $\mathrm{H}^{+}$), $1707\left(\mathrm{M}^{+}\right)$; HRMS calcd for $\mathrm{C}_{116} \mathrm{H}_{128} \mathrm{O}_{10} \mathrm{~N}_{2}$ 1708.9569, found 1708.9546.

Doubly Bridged 9,10-Bis-isoxazolylanthryl Substituted Biscalix[4]arene, 10. A mixture of $9(0.10 \mathrm{~g}, 0.05 \mathrm{mmol})$ and 4 $(0.02 \mathrm{~g}, 0.06 \mathrm{mmol})$ in THF $(15 \mathrm{~mL})$ was stirred and heated at reflux for $24 \mathrm{~h}$ under $\mathrm{N}_{2}$ system. The solvent was removed under a vacuum, and the residue was purified by silica gel column chromatography with ethyl acetate $/ n$-hexane as eluent to give $0.04 \mathrm{~g}(32.2 \%)$ of biscalix[4] arene 10 as a yellow solid: $\mathrm{mp}>260{ }^{\circ} \mathrm{C}$ (decomposed); $R_{f}=0.23$ (ethyl acetate $/ n$-hexane (v/v, 1:4)); ${ }^{1} \mathrm{H}$ NMR $(300 \mathrm{MHz}$, $\left.\mathrm{CDCl}_{3}\right) \delta_{\mathrm{H}} 7.72-7.69(\mathrm{~m}, 8 \mathrm{H}), 7.32-7.11(\mathrm{~m}, 8 \mathrm{H}), 6.94(\mathrm{~s}, 8 \mathrm{H}), 6.32$ $(\mathrm{s}, 4 \mathrm{H}), 5.24(\mathrm{~s}, 8 \mathrm{H}), 4.37(\mathrm{~d}, 8 \mathrm{H}, J=13.2 \mathrm{~Hz}), 3.47(\mathrm{~d}, 8 \mathrm{H}, J=13.2$ $\mathrm{Hz}), 1.28(\mathrm{~s}, 36 \mathrm{H}), 1.08(\mathrm{~s}, 36 \mathrm{H}) \mathrm{ppm} ;{ }^{13} \mathrm{C} \mathrm{NMR}(75.5 \mathrm{MHz}) \delta_{\mathrm{C}}$ $168.2(\mathrm{Cq}), 160.6(\mathrm{Cq}), 150.5(\mathrm{Cq}), 149.8(\mathrm{Cq}), 147.9(\mathrm{Cq}), 141.9$ $(\mathrm{Cq}), 132.6(\mathrm{Cq}), 129.8(\mathrm{Cq}), 127.5(\mathrm{Cq}), 126.4(\mathrm{CH}), 126.0(\mathrm{CH})$, $125.8(\mathrm{CH}), 125.3(\mathrm{CH}), 125.2(\mathrm{Cq}), 107.1(\mathrm{CH}), 68.2\left(\mathrm{CH}_{2}\right), 34.1$ (Cq), $33.9(\mathrm{Cq}), 32.0\left(\mathrm{CH}_{2}\right), 31.7\left(\mathrm{CH}_{3}\right), 31.0\left(\mathrm{CH}_{3}\right)$ ppm; FAB-MS $m / z 1970\left(\mathrm{M}+\mathrm{H}^{+}\right)$; HRMS (FAB) calcd for $\mathrm{C}_{132} \mathrm{H}_{136} \mathrm{O}_{12} \mathrm{~N}_{4}$ 1969.0155, found 1969.0137 .

X-ray Crystal Data for 10. $\mathrm{C}_{137} \mathrm{H}_{155} \mathrm{C}_{13} \mathrm{~N}_{4} \mathrm{O}_{16} ; M=2220.00 ; T=$ $150(2) \mathrm{K}$; triclinic; $a=11.9430(8) \AA, b=16.0684(10) \AA, c=$ 16.8946(8) $\AA ; \alpha=82.311(4)^{\circ}, \beta=81.842(5)^{\circ}, \gamma=78.038(5)^{\circ} ; V=$ $3121.4(3) \AA^{3}$; space group $P \overline{1} ; Z=1 ; \rho_{\text {calcd }}=1.181 \mathrm{mg} \mathrm{m}^{-3}$; crystal dimensions $0.20 \times 0.15 \times 0.10 \mathrm{~mm}^{3} ; \lambda=1.54178 \AA$ 作 29213 reflections collected; 11277 independent reflections $\left[R_{\text {int }}=0.0379\right]$; absorption coefficient $1.176 \mathrm{~mm}^{-1} ; 1184$ parameter refined on $F^{2} ; R_{1}=0.1173$, $w R_{2}\left[F^{2}\right]=0.3066$ (all data); GOF on $F^{2}=2.333 ; \Delta \rho_{\max }=1.774$ e $\AA^{-3}$. CCDC-853852 contains the supplementary crystallographic data for this paper. These data can be obtained free of charge from the Cambridge Crystallographic Data Centre via www.ccdc.cam.ac.uk/ data_request/cif.

3,3'-Anthracene-9,10-diylbis \{5-[4-tert-butylphenoxy)methyl]isoxazole\}, 11. A mixture of 1-tert-butyl-4-(prop-2-ynyloxy)benzene $(0.20 \mathrm{~g}, 1.07 \mathrm{mmol})$ and $4(0.12 \mathrm{~g}, 0.48 \mathrm{mmol})$ in THF $(25$ $\mathrm{mL}$ ) was stirred and heated at reflux for $24 \mathrm{~h}$ under a $\mathrm{N}_{2}$ system. The solvent was removed under a vacuum, and the residue was purified by silica gel column chromatography with ethyl acetate/ $n$-hexane as eluent to give $0.16 \mathrm{~g}(52.1 \%)$ of 11 as a yellow solid: $\mathrm{mp} 231-233^{\circ} \mathrm{C}$; $R_{f}=0.45$ (ethyl acetate $/ n$-hexane (v/v, $\left.1: 4\right)$ ); ${ }^{1} \mathrm{H}$ NMR $(300 \mathrm{MHz}$, $\left.\mathrm{CDCl}_{3}\right) \delta_{\mathrm{H}} 7.88-7.85(\mathrm{~m}, 4 \mathrm{H}), 7.49-7.45(\mathrm{~m}, 4 \mathrm{H}), 7.38(\mathrm{~d}, 4 \mathrm{H}, J=$ $8.7 \mathrm{~Hz}), 7.00(\mathrm{~d}, 4 \mathrm{H}, J=8.7 \mathrm{~Hz}), 6.64(\mathrm{~s}, 2 \mathrm{H}), 5.37(\mathrm{~s}, 4 \mathrm{H}), 1.31(\mathrm{~s}$, $18 \mathrm{H}) \mathrm{ppm} ;{ }^{13} \mathrm{C} \mathrm{NMR}\left(75.5 \mathrm{MHz}, \mathrm{CDCl}_{3}\right) \delta_{\mathrm{C}} 168.9(\mathrm{Cq}), 160.8(\mathrm{Cq})$, $155.5(\mathrm{Cq}), 144.7(\mathrm{Cq}), 130.1(\mathrm{Cq}), 126.5(\mathrm{CH}), 125.9(\mathrm{CH}), 125.5$ $(\mathrm{Cq}), 114.4(\mathrm{CH}), 106.8(\mathrm{CH}), 61.7\left(\mathrm{CH}_{2}\right), 34.1(\mathrm{Cq}), 31.5\left(\mathrm{CH}_{3}\right)$ 
ppm; FABMS $m / z 637\left(\mathrm{M}+\mathrm{H}^{+}\right), 636\left(\mathrm{M}^{+}\right)$; HRMS calcd for $\mathrm{C}_{42} \mathrm{H}_{40} \mathrm{O}_{4} \mathrm{~N}_{2}$ 636.2988, found 636.2994.

(3Z, 3'Z)-4, 4'-Anthracene-9, 10-diylbis[4-amino-1-(4-tertbutylphenoxy)but-3-en-2-one], 12a-b. A mixture of $11(0.07 \mathrm{~g}$, $0.11 \mathrm{mmol}), \mathrm{Mo}(\mathrm{CO})_{6}(0.07 \mathrm{~g}, 0.25 \mathrm{mmol})$ and $\mathrm{H}_{2} \mathrm{O}(0.2 \mathrm{~mL})$ in $\mathrm{THF} / \mathrm{CH}_{3} \mathrm{CN}(1 \mathrm{~mL} / 10 \mathrm{~mL})$ was stirred and heated at reflux for $24 \mathrm{~h}$. The solvent was removed under a vacuum, and the residue was dissolved in $10 \mathrm{~mL}$ of dichloromethane. Then, to the solution was added $10 \mathrm{~mL}$ of $\mathrm{NH}_{4} \mathrm{OH}$ (aq) to remove remaining molybdenum salts. After stirring for $1 \mathrm{~h}$, the organic layer was washed with water and 1 M EDTA (aq). The organic phase was dried over $\mathrm{MgSO}_{4}$, and the solvent was removed under reduced pressure. The residue was purified by neutral silica gel column chromatography with ethyl acetate $/ n$ hexane $(1 / 5)$ as eluent to give trace amount of yellow solid 12 (atropisomers): $\mathrm{mp}>180{ }^{\circ} \mathrm{C}$ (decomposed); $R_{f}=0.20$ (ethyl acetate/ $n$-hexane (v/v, 1:3)); ${ }^{1} \mathrm{H}$ NMR $\left(300 \mathrm{MHz}, \mathrm{CDCl}_{3}\right) \delta_{\mathrm{H}} 10.44(\mathrm{bs}, 2 \mathrm{H})$, 8.11-8.07 (m, 4H), 7.61-7.46 (m, 4H), 7.28-7.25 (m, 2H), 6.91$6.79(\mathrm{~m}, 2 \mathrm{H}), 5.82(\mathrm{~s}, 1 \mathrm{H}), 5.78(\mathrm{~s}, 1 \mathrm{H}), 5.50(\mathrm{bs}, 1 \mathrm{H}) 5.43(\mathrm{bs}, 2 \mathrm{H})$, 4.63, (s, 2H), $4.62(\mathrm{~s}, 4 \mathrm{H}), 1.28-1.26(\mathrm{~m}, 9 \mathrm{H}) \mathrm{ppm} ;{ }^{13} \mathrm{C}$ NMR $(75.5$ $\left.\mathrm{MHz}, \mathrm{CDCl}_{3}\right) \delta_{\mathrm{C}} 195.6(\mathrm{Cq}), 195.6(\mathrm{Cq}), 161.0(\mathrm{Cq}), 160.9(\mathrm{Cq})$, $155.9(\mathrm{Cq}), 143.8(\mathrm{Cq}), 132.8(\mathrm{Cq}), 127.9(\mathrm{Cq}), 126.8(\mathrm{CH}), 126.2$ $(\mathrm{CH}), 125.6(\mathrm{CH}), 114.0(\mathrm{CH}), 95.8(\mathrm{CH}), 72.0\left(\mathrm{CH}_{2}\right), 34.1(\mathrm{Cq})$, $31.5\left(\mathrm{CH}_{3}\right)$ ppm; HRMS (FAB) calcd for $\mathrm{C}_{42} \mathrm{H}_{40} \mathrm{~N}_{2} \mathrm{O}_{4}$ 636.2988, found 636.2994 .

\section{ASSOCIATED CONTENT}

\section{S Supporting Information}

Crystallographic data for compound 10 (CIF), data calculated by molecular modeling using $\mathrm{DMol}^{3}$ for the optimized geometry of complex $10 \cdot \mathrm{G} 6,{ }^{1} \mathrm{H}$ and ${ }^{13} \mathrm{C}$ NMR spectra for all products 5-12, and spectroscopic data. This material is available free of charge via the Internet at http://pubs.acs.org.

\section{AUTHOR INFORMATION}

\section{Corresponding Author}

*E-mail: wschung@nctu.edu.tw.

\section{Notes}

The authors declare no competing financial interest.

\section{ACKNOWLEDGMENTS}

We thank the National Science Council (NSC) and the MOE ATU program of the Ministry of Education, Taiwan, the Republic of China, for financial support.

\section{REFERENCES}

(1) (a) Marchand, A. P.; Chong, H.-S.; Takhi, M.; Power, T. D. Tetrahedron 2000, 56, 3121. (b) Webber, P. R. A.; Beer, P. D.; Chen, G. Z.; Felix, V.; Drew, M. G. B. I. Am. Chem. Soc. 2003, 125, 5774. (c) Chen, C.-F.; Lu, L.-G.; Hu, Z.-Q.; Peng, X.-X.; Huang, Z.-T. Tetrahedron 2005, 61, 3853.

(2) (a) Haino, T.; Yamanaka, Y.; Araki, H.; Fukazawa, Y. Chem. Commun. 2002, 402. (b) Nabeshima, T.; Saiki, T.; Sumitomo, K.; Akine, S. Tetrahedron Lett. 2004, 45, 4719.

(3) Ohseto, F.; Sakaki, T.; Araki, K.; Shinkai, S. Tetrahedron Lett. 1993, 34, 2149.

(4) (a) Wang, J.; Bodige, S. G.; Watson, W. H.; Gutsche, C. D. J. Org. Chem. 2000, 65, 8260. (b) Haino, T.; Fukunaga, C.; Fukazawa, Y. Org. Lett. 2006, 8, 3545.

(5) Tanner, C. M.; Kamel, F.; Ross, G. W.; Hoppin, J. A.; Goldman, S. M.; Korell, M.; et al. Environ. Health Perspect. 2011, 119 (6), A259 DOI: $10.1289 /$ ehp. 1002839 .

(6) (a) Hwang, G. T.; Kim, B. H. Tetrahedron 2002, 58, 9019. (b) Hwang, G. T.; Kim, B. H. Tetrahedron Lett. 2000, 41, 5917. (c) Pierro, T.; Gaeta, C.; Troisi, F.; Neri, P. Tetrahedron Lett. 2009, 50, 350 .
(7) (a) Su, Y.-S.; Chen, C.-F. Org. Lett. 2010, 12, 1888. (b) Xu, Z.; Jiang, L.; Feng, Y.; Zhang, S.; Liang, J.; Pan, S.; Yang, Y.; Yang, D.; Cai, Y. Org. Biomol. Chem. 2011, 9, 1237.

(8) (a) Zong, Q.-S; Chen, C.-F. Org. Lett. 2006, 8, 211. (b) Peng, X.X.; Lu, H.-Y.; Han, T.; Chen, C.-F. Org. Lett. 2007, 9, 895. (c) Zhao, J.M.; Zong, Q.-S.; Han, T; Xiang, J.-F.; Chen, C.-F. I. Org. Chem. 2008, 73, 6800. (d) Jiang, Y.; Cao, J.; Zhao, J.-M.; Xiang, J.-F.; Chen, C.-F. I. Org. Chem. 2010, 75, 1767. (e) Hu, S.-Z.; Chen, C.-F. Chem.-Eur. J. 2011, 17, 5423.

(9) (a) Li, C.; Xu, Q.; Li, J.; Yaoa, F.; Jia, X. Org. Biomol. Chem. 2010, 8, 1568. (b) Ogoshi, T.; Hashizume, M.; Yamagishi., T.-A.; Nakamoto, Y. Chem. Commun. 2010, 46, 3708.

(10) Lagona, J.; Wagner, B. D.; Isaacs, L. J. Org. Chem. 2006, 71, 1181.

(11) (a) Hwang, G. T.; Kim, B. H. Tetrahedron Lett. 2000, 41, 10055. (b) Morales-Sanfrutos, J.; Ortega-Muñoz, M.; Lopez-Jaramillo, J.; Hernandez-Mateo, F.; Santoyo-Gonzalez, F. I. Org. Chem. 2008, 73, 7768.

(12) (a) Shu, C.-M.; Lee, G.-H.; Peng, S.-M.; Chung, W.-S. J. Chin. Chem. Soc. 2000, 47, 173. (b) Shiao, Y.-J.; Chiang, P.-C.; Senthilvelan, A.; Tsai, M.-T.; Lee, G.-H.; Chung, W.-S. Tetrahedron Lett. 2006, 47, 8383.

(13) (a) Nitta, M.; Kobayashi, T. J. Chem. Soc., Perkin Trans. 1985, 1, 1401. (b) Tranmer, G. K.; Tam, W. Org. Lett. 2002, 4, 4101. (c) Kociolek, M. G.; Straub, N. G.; Marton, E. I. Lett. Org. Chem. 2005, $2,280$.

(14) (a) Senthilvelan, A.; Lee, G.-H.; Chung, W.-S. Tetrahedron Lett. 2006, 47, 7179. (b) Senthilvelan, A.; Ho, I.-T.; Chang, K.-C.; Lee, G.H.; Liu, Y.-H.; Chung, W.-S. Chem.-Eur. I. 2009, 15, 6152. (c) Ho, I.T.; Chu, J.-H.; Chung, W.-S. Eur. I. Org. Chem. 2011, 1472. (d) Ho, I.T.; Huang, K.-C.; Chung, W.-S. Chem.-Asian I. 2011, 6, 2738.

(15) (a) Port, A.; Moragas, M.; Sánchez-Ruiz, X.; Jaime, C.; Virgili, A.; Alvarez-Larena, A.; Piniella, J. F. J. Org. Chem. 1997, 62, 899. (b) Irngartinger, H.; Weber, A.; Escher, T.; Fettel, P. W.; Gassner, F. Eur. I. Org. Chem. 1999, 2087. (c) Lunazzi, L.; Mazzanti, A.; Minzoni, M.; Anderson, J. E. Org. Lett. 2005, 7, 1291. (d) Schwab, G.; Stern, D.; Stalke, D. L. Org. Chem. 2008, 73, 5242. (e) Nikitin, K.; Müller-Bunz, H.; Ortin, Y.; Muldoon, J.; McGlinchey, M. I. Org. Lett. 2011, 13, 256. (f) Friebolin, H. Basic One- and Two-Dimensional NMR Spectroscopy; VCH: Weinheim, Germany, 2005; p 313. (g) $\Delta G^{\neq}$was estimated to be $23 \mathrm{kcal} \mathrm{mol}^{-1}$ on the basis of variable temperature NMR experiments (see Figures S4 and S5, Supporting Information). The activation free energies were obtained using equations from ref $15 \mathrm{f}$. $k_{\mathrm{c}}$ $=2.22 \Delta \nu, \Delta G^{\neq}=4.58 T_{\mathrm{c}}\left(10.32+\log \left(T_{\mathrm{c}} / k_{\mathrm{c}}\right)\right) 10^{-3} \mathrm{kcal} / \mathrm{mol}$.

(16) Normal phase HPLC was performed with a Gilson 321-H1 pump system with a 506C interface, a Rheodyne $7725 \mathrm{I}$ injector, a Gilson 155 UV-vis detector (Gilson, Inc., Middleton, WI). For silica column (Hypersil, $4.6 \times 250 \mathrm{~mm}, 5 \mu \mathrm{m}$ ), the mobile phase was eluted from hexane to hexane/EA (v/v, 2:3) over $30 \mathrm{~min}$ at a flow rate of 1 $\mathrm{mL} / \mathrm{min}$. For CHIRALPAK AS-H and CHIRACEL OD-H columns (both are $4.6 \times 250 \mathrm{~mm}, 5 \mu \mathrm{m}$, Daicel Chemical Industrial, Ltd., Tokyo), the mobile phase of 2-propanol/hexane (v/v, 1:9) was eluted isocratically at a flow rate of $0.5 \mathrm{~mL} / \mathrm{min}$.

(17) (a) Nowak, W.; Wierzbowska, M. THEOCHEM 1996, 368, 223. (b) Nori-shargha, D.; Asadzadeha, S.; Ghanizadehb, F.-R.; Deyhimic, F.; Aminic, M. M.; Jameh-Bozorghi, S. THEOCHEM 2005, 717, 41. (c) Nikitin, K.; Fleming, C.; Müller-Bunz, H.; Ortin, Y.; McGlinchey, M. J. Eur. I. Org. Chem. 2010, 5203.

(18) The rotation barrier was calculated on the basis of the variable temperature NMR experiment using the equation in ref $15 \mathrm{~g}$.

(19) The relative fluorescence quantum yields were determined by comparison of the integrated area of the emission spectra of the samples with the reference compound 9,10-diphenylanthracene $\left(\Phi_{\mathrm{F}}=\right.$ $0.90 \pm 0.02$ in cyclohexane). For the guest-free studies, biscalixarenes 7,10 and control compound 11 were at $10 \mu \mathrm{M}$ concentration in $\mathrm{MeOH} / \mathrm{CHCl}_{3}$ (v/v, 1:2). For the complexation studies, 200 equiv of G6 (methyl viologen) was added to $10 \mu \mathrm{M}$ solution of biscalixarenes 7, 10 or control compound 11 in $\mathrm{MeOH} / \mathrm{CHCl}_{3}$ (v/v, 1:2). Emission spectra of these samples were integrated from 390 to $650 \mathrm{~nm}$ with 
excitation at $388 \mathrm{~nm}$ for 7 and 384 for $\mathbf{1 1}$ and from 395 to $650 \mathrm{~nm}$ for 10 with excitation at $391 \mathrm{~nm}$. The relative fluorescent quantum yield for 7,10 , and 11 are $0.70 \pm 0.02,0.80 \pm 0.02$, and $0.96 \pm 0.02$, respectively. The relative quantum yields were calculated using equation: $\Phi_{\mathrm{F}}=\left(A_{\text {ref }} / A\right) \times\left(F / F_{\text {ref }}\right) \times\left(n_{\text {chloroform }}^{2} / n_{\text {cyclohxane }}^{2}\right) \times \Phi_{\text {ref }}$ where $A$ is the absorbance at the excitation wavelength, $F$ is the integrated emission area, and $n$ is the refractive index of the solvent $\left(n_{\text {chloroform }}=1.4459, n_{\text {cyclohexane }}=1.4262\right.$ at $\left.25{ }^{\circ} \mathrm{C}\right)$. See related references: (a) Eaton, D. F. Pure Appl. Chem. 1988, 60, 1107. (b) Dawson, W. R.; Windsor, M. W. J. Phys. Chem. 1968, 72, 3251.

(20) The association constant was calculated by using a SternVolmer plot; see: Valeur, B. Molecular Fluorescence: Principles and Applications; Wiley-VCH: Weinheim, Germany, 2001; p 77.

(21) We thank one of the reviewers for this suggestion. (a) Morris, K. F.; Johnson, C. S. I. Am. Chem. Soc. 1992, 114, 3139. (b) Keresztes, I.; WIlliard, P. G. I.Am. Chem. Soc. 2000, 122, 10228. (c) Balayssac, S.; Gilard, V.; Delsuc, M.-A.; Malet-Martino, M. Spectrosc. Eur. 2009, 21, 9.

(22) (a) Delley, B. J. Chem. Phys. 1990, 92, 508. (b) Delley, B. I. Chem. Phys. 2000, 113, 7756.

(23) (a) Benedek, N. A.; Snook, I. K.; Latham, K.; Yarovsky, I. J. Chem. Phys. 2005, 122, 144102. (b) Kusama, H.; Orita, H.; Sugihara, H. Langmuir 2008, 24, 4411. (c) Inada, Y.; Orita, H. I. Comput. Chem. 2008, 29, 225. 